\title{
Crustal evolution of the South American Platform, based on Nd isotopic systematics on granitoid rocks
}

Instituto de Geociências - Universidade de São Paulo, Rua do Lago 562 CEP 05508-900, São Paulo - Brasil; e-mail: ucordani@.usp.br

\begin{abstract}
A comprehensive interpretation of the crustal evolution of the South American Platform is made, based on several hundred Sm-Nd determinations from granitoid rocks of Brazil and part of the neighbouring countries. The histogram of the $T_{D M}$ model ages indicates small amounts of continental crust older than 3.3 Ga surviving within Archean terrains formed between 3.1 and 2.7 $\mathrm{Ga}$. The main period of crust formation was between 2.2 and $2.0 \mathrm{Ga}$, corresponding to the Transamazonian orogenic cycle, and accretion of juvenile material continued until Neoproterozoic times, but at much slower rates.
\end{abstract}

The Transbrasiliano megasuture separates a large northwestern continental mass, including the Amazonian and São Luis cratons, from a southeastern mass, formed by a collage of cratonic fragments, of which the São Francisco and Rio de La Plata are the largest, which took part in the agglutination of the West Gondwana supercontinent in the Neoproterozoic. On both continental masses, crustal evolution was similar between 3.0 and $1.7 \mathrm{Ga}$, suggesting that they were possibly contiguous, within a Paleoproterozoic supercontinent.

\section{Introduction}

The isotopic composition of radiogenic isotopes formed by radioactive parents with very long half-lives, such as $\mathrm{Sr}, \mathrm{Nd}, \mathrm{Pb}, \mathrm{Hf}$, and $\mathrm{Os}$, are largely used to constrain the crustal evolution of geotectonic units. This work will deal with the so-called South American Platform, the tectonically stable continental mass which acted as the cratonic area for the tectonomagmatic episodes which occurred in the Phanerozoic within the Andean belt.

Cordani et al. (1988) have already produced a synthesis on this subject, employing the $\mathrm{Sr}$ isotopic composition of granitoid rocks, obtained from more than 10,000 individual measurements on samples collected all over the continental area, and performed mainly at the Geochronology Research Center of the University of São Paulo (CPGeo-USP). In recent years, some Sm-Nd studies carried out in a few Brazilian regions became available, such as the ones by Pimentel and Fuck (1992), and Van Schmus et al. (1995). A comprehensive Sm-Nd study was made by Sato (1998) for the entire South American Platform, which has lead to a better knowledge of its crustal evolution.
It is known that both parent-daughter pairs $\mathrm{Rb}-\mathrm{Sr}$ and $\mathrm{Sm}-\mathrm{Nd}$ are strongly fractionated during the complex processes which form "juvenile" continental crust from primary mantle sources. However, in clear contrast to the $\mathrm{Rb}-\mathrm{Sr}$ system, the subsequent crustal processes normally produce only minor or even negligible changes in the $\mathrm{Sm} / \mathrm{Nd}$ ratio, a property that has made the $\mathrm{Nd}$ isotopic studies a very powerful tool in characterising continental crustal provinces.

Granitoid rocks, in the broader sense, are the main constituents of the continental crust. They may be formed through many different petrogenetic processes, and measurements of their isotopic systematics can be employed as tracers for their origin and for the nature of their source materials. For this synthesis, magmatic suites ranging from granodiorites and tonalites to true granites were employed, as well as granitoid rocks from medium to high-grade regional metamorphic terrains, which are the prevalent units of the gneissicmigmatitic complexes so common in shield areas.

\section{Geotectonic provinces of the South American Platform}

If we accept that magmatism associated with mantle-continental crust differentiation processes is common throughout geologic time, then at least two main petrogenetic processes can be envisaged in order to produce very large volumes of granitoid rocks :

1 - Formation of juvenile granitoids within magmatic arcs, in association with subduction of oceanic lithosphere. They may derive from different types of magma sources, including the hot mantle wedge above the subduction zone.

2 - Formation of granitoids from pre-existing crustal protoliths, by partial melting within the continental crust. This may occur in association with both orogenic and intraplate magmatism, by melting of the lower crust, for instance, when heated by underplated primary basaltic liquids.

Figure 1 shows the main geotectonic provinces of South America, with the indication of the Andean belt, and the approximate extent of the influence of the Phanerozoic orogenic events. In this figure, the Late Proterozoic geotectonic situation of the South American Platform is shown, with the large Amazonian (AM) and São Francisco (SF) cratons, the small Rio de La Plata (RP), São Luis (SL) and Luiz Alves (LA) cratonic fragments, and the mobile belts associated to the Brasiliano-Pan African orogenic Cycle. These correspond to the Paraguay-Araguaia-Tocantins belt, marginal to the Amazonian craton; the Brasilia and Araçuai belts, marginal to the São Francisco craton; the Dom Feliciano belt, marginal to the Rio de La Plata, and Luiz Alves cratonic fragments. The Borborema province (B) in northeastern Brazil, the Tocantins province $(\mathrm{T})$ in Central Brazil, and the Mantiqueira province (M) in eastern and southeastern Brazil, include some of the marginal belts already referred, as well as older crustal fragments (basement inliers), all them affected by the Late Proterozoic orogenies. It is beyond the 
scope of this article to describe with pertinent details the mentioned geotectonic units, and the reader is invited to consult the already mentioned work by Sato (1998). Some of the geotectonic units are considered further in this issue of Episodes, and in general they were adequately described in the reference work of Schobbenhaus et al. (1984), on the geologic map of Brazil at the 2,500,000 scale.

\section{Tectonic significance of $\mathrm{Sr}$ and $\mathrm{Nd}$ isotopic data}

In the case of strontium, the initial ${ }^{87} \mathrm{Sr} /{ }^{86} \mathrm{Sr}$ ratio for a suite of cogenetic granitoid rocks is the main indicator of the source material. In the cited work by Cordani et al. (1988), this indicator was used together with some other geological criteria (stratigraphic, petrogenetic, structural) in order to estimate the relative amount of juvenile continental crust accreted during each time interval of geological time, for the area of the Brazilian Shield. Curve 1 on figure 10 represents the fraction of continental growth (or survival) versus time, according to Cordani et. al. (1988).

In Sato's (1998) study, $\mathrm{Nd}$ isotopic compositions and $\mathrm{Sm}-\mathrm{Nd}$ model ages were obtained for several hundred granitoid rocks, many of which had already been analysed for $\mathrm{Sr}$ isotopes at the CPGeoUSP. The association of the $\mathrm{Sm}-\mathrm{Nd}$ measurements with the available geochronological data obtained by other methods, permitted an improved interpretation for the origin of the granitoid rocks under examination.

The authors are aware of the limitations of the Sm-Nd model ages for the interpretation of the crustal evolution of a given terrain. $\mathrm{T}_{\mathrm{DM}}$ model ages are the most used in such interpretations. They are related to the evolution of the mantle during geologic time, admitting episodes of fractioning associated to the extraction of basaltic magmas, with the residual material within the mantle sources becoming increasingly enriched in the $\mathrm{Sm} / \mathrm{Nd}$ ratio but depleted in incompatible elements.

Taking into account both the natural variations in mantle material, demonstrated by the existence of geochemically distinct reservoirs, such as DMM, HIMU, EM1, EM2, and others, and also the possibilities of mixtures between such different reservoirs and crustal sources, the Sm-Nd $\mathrm{T}_{\mathrm{DM}}$ model ages must be interpreted very carefully. At any rate, the depleted mantle model is employed as a reasonable first approximation, because oceanic lithosphere has been produced throughout geologic time. It is known to be transient, recycling back to the mantle along B-subduction zones, but part of its material differentiates and remains near the surface of the Earth as continental crust.

$\mathrm{Sm}-\mathrm{Nd} \mathrm{T}_{\mathrm{DM}}$ model ages have been considered to be "crust-formation ages", since they are obtained calculating the time when a given sample had an isotopic composition identical to the depleted mantle, presumed to be its ultimate source. Their validity depends on at least two assumptions: 1, That only a short time elapsed between the formation of the mantle-derived magma and the final emplacement of the differentiated material in the continental crust, with Sm to $\mathrm{Nd}$ fractionation, and acquisition of a continental $\mathrm{Sm} / \mathrm{Nd}$ ratio; and 2, That the $\mathrm{Sm} / \mathrm{Nd}$ ratio of the sample was not modified by subsequent geological events. Because such assumptions may be valid only in a limited number of cases, the Sm-Nd systematics usually provides an estimate of the average time that the material in the sample has been resident in the continental crust (Arndt and Goldstein, 1987).

The use of special interpretative diagrams, and the association of the Sm-Nd measurements with other geochronological data, allowed to indicate whether the granitoids under investigation could be considered "juvenile", formed by mantle-continental crust differentiation processes as described in the previous paragraph, or "reworked" by melting of previously crustal protoliths. Juvenile material would be indicated by concordant (or slightly discordant)

\section{CRUSTAL PROVINCES OF SOUTH AMERICA}

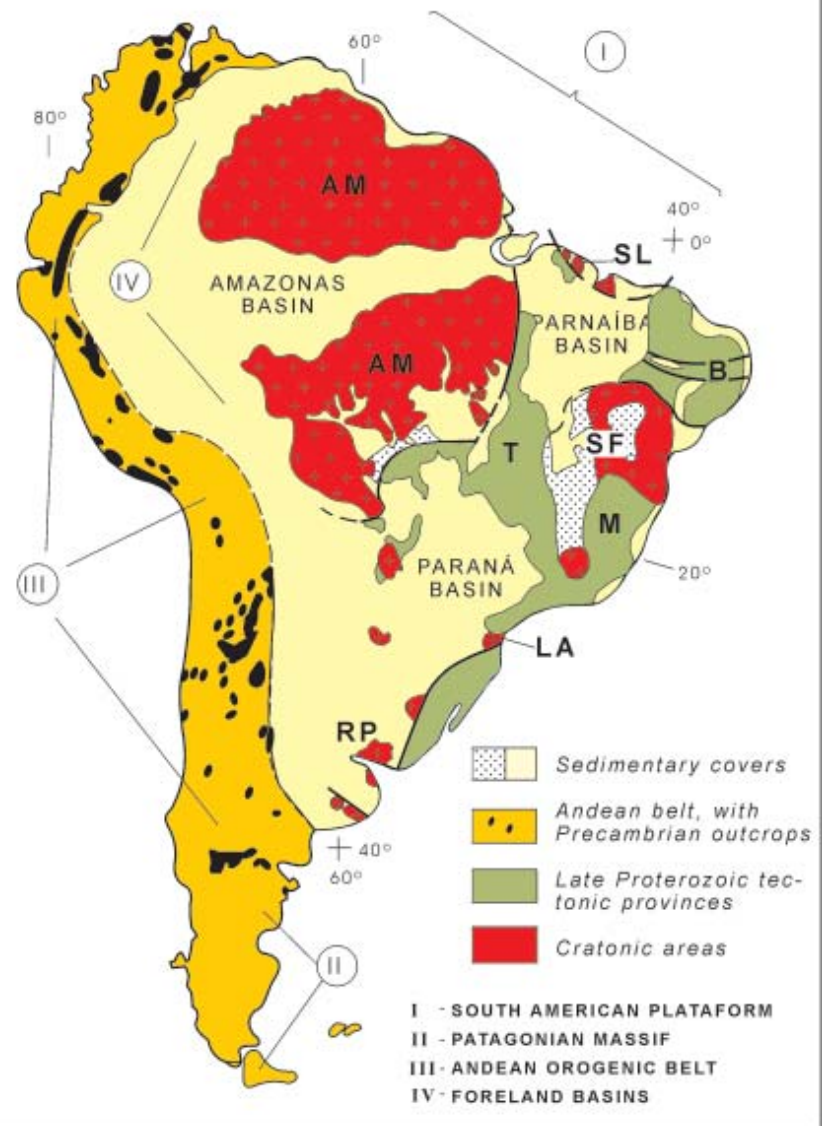

Figure 1 Crustal provinces of South America.

$\mathrm{Rb}-\mathrm{Sr}$ (or U-Pb) and $\mathrm{Sm}-\mathrm{Nd}$ apparent age values, positive (or slightly negative) $\varepsilon_{\mathrm{Nd}(\mathrm{T})}$ values, and low ${ }^{87} \mathrm{Sr} /{ }^{86} \mathrm{Sr}$ initial ratios.

\section{Results and discussion}

Figures 2 to 7 show the evolution during geologic time of the Nd isotopic composition of different granitoids, representative of important units within the various geotectonic domains in the South American Platform. All diagrams include both the mantle evolution curve (CHUR, where $\varepsilon_{\mathrm{Nd}}=$ zero) and the depleted mantle (DM) evolution curve. Oblique lines plotted across the areas of the diagrams are related to different groups of granitoid rocks, characterized by $\mathrm{Nd}$ isotopic determinations which display a reasonably coherent pattern, and such lines show the average tendency of each group. In the figures, the average present-day $\varepsilon_{\mathrm{Nd}(\mathrm{zero})}$ value, always negative, is plotted at the left end of each straight line.

The slopes of the oblique lines correspond to the general trends of the analysed samples. In all cases the ${ }^{147} \mathrm{Sm} /{ }^{144} \mathrm{Nd}$ ratios related to such trends are close to 0.11 , typical of the products of singlestage differentiation from mantle to continental crust. Samples with ${ }^{147} \mathrm{Sm} /{ }^{144} \mathrm{Nd}$ outside the range $0.088-0.125$ were excluded, in order to avoid systems almost certainly not formed in a "single stage" event. In all of the lines, radiometric ages of each unit, obtained by $\mathrm{Rb}-\mathrm{Sr}$ or $\mathrm{U}-\mathrm{Pb}$ methods, were indicated by small circles, or ellipses, drawn to represent roughly the spread in age and initial $\varepsilon_{\mathrm{Nd}}$ values obtained in the analytical work. Finally, for each of the units, the spread in the calculated Sm-Nd T $\mathrm{DM}$ model ages was also indicated at the top of each diagram, close to the DM evolution line, together with the actual number of samples belonging to each group. 


\section{Amazonian Craton}

The general geological knowledge of this large region of South America remains at reconnaissance scale. Teixeira et al. (1989) reviewed its geotectonic evolution and summarised the available radiometric control. A large continental mass was formed during the Early Proterozoic after an important tectonomagmatic activity within the Maroni-Itacaiunas belt, incorporating a few Archean nuclei, within the so-called Central Amazonian province. Continental growth continued through Proterozoic times by the agglutination of successive juvenile magmatic arcs, making up the VentuariTapajós and Rio Negro-Juruena provinces. Subsequently, this very large continental mass was welded to a smaller one during two successive collisional events, the Rondonian and Sunsás orogenies, establishing the Amazonian craton in Late Proterozoic times.

Figure 2 presents the still very scanty Nd isotopic data available for the Amazonian craton. In this figure, most of the ellipses representative of the geotectonic units plot in the vicinity of the mantle evolution curve (CHUR), exhibiting positive or slightly negative initial $\varepsilon_{\mathrm{Nd}}$ values, indicating that juvenile material, formed through mantle differentiation processes, is widespread. This is valid for the Carajás granitoid rocks of Archean age (CA1), as well as for the Early to Mid Proterozoic granitoids belonging to the younger tectonic provinces, where most of the studied samples yielded Sm-Nd $\mathrm{T}_{\mathrm{CHUR}}$ model ages practically concordant with the $\mathrm{Rb}-\mathrm{Sr}$ or U-Pb age values in the same samples. These are the granitoids belonging to the Maroni-Itacaiunas (MI1) mobile belt, the Ventuari-Tapajós (VT) and Rio Negro-Juruena (RNJ) magmatic arc systems, as well as the Rondonian (R) and Sunsás (S) collision belts.

A few important exceptions, indicating reworking from crustal material, are : 1) the Cupixi high-grade gneisses which are part of the basement for the Maroni-Itacaiunas province (MI2 in Figure 2), exhibiting an Archean age, and 2) the Early to Mid Proterozoic intrusive granites into the Carajás region (CA2). A few granitoid rocks (TO1 and TO2) collected from the basement of the Tocantins belt, marginal to the Amazonian craton, yielded Archean signatures, and could correspond to the same terrain as the Central Amazonian province, although affected by the Late Proterozoic Brasiliano orogeny.

\section{São Francisco Craton}

In contrast to the Amazonian Craton, a large number of radiometric ages are available for the São Francisco craton. This geotectonic unit has good exposures of its old basement in the states of Minas Gerais and Bahia, as well an extensive cratonic sedimentary cover, the Bambui Group, deposited in the Late Proterozoic.

Figure 3 shows the Nd isotopic data available for the region. It includes the oldest rocks so far identified for the South American

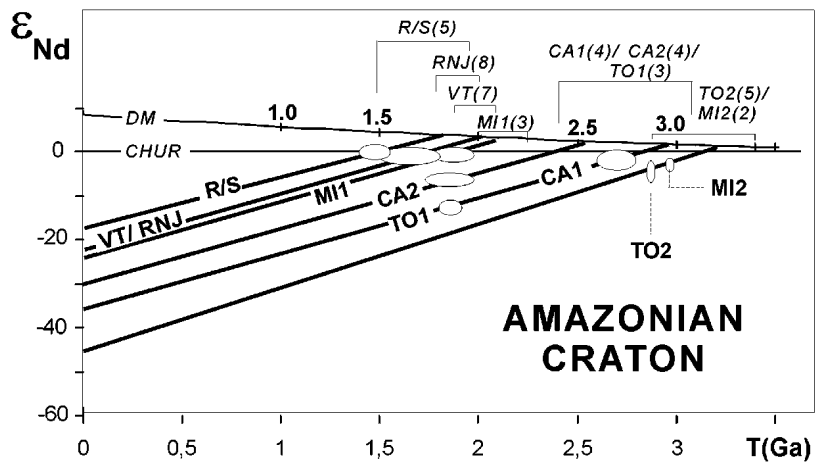

Figure 2 Diagram of $\mathrm{Nd}$ isotopic evolution for the Amazonian craton. $C A 1$ and $C A 2$ = Central Amazonian province; $M I 1$ and MI2 = Maroni-Itacaiunas province $; V T=$ Ventuari-Tapajós province $; \boldsymbol{R N J}=$ Rio Negro-Juruena province; $R=$ Rondonian belt; $S=$ Sunsás belt; TO1 and TO2 = Basement inliers within Tocantins belt. continent, the granitoids of Sete Voltas and Boa Vista (SV), which are found within two mantled gneissic domes of the ContendasMirante belt, tectonically active during Early Proterozoic times. Their radiometric ages are slightly younger than $3.5 \mathrm{Ga}$ (Nutman and Cordani, 1993), and their Nd isotopic signature points out to juvenile mantle-type protoliths. In contrast, the Lagoa do Morro gneisses (LM), which also belong to the basement of the Contendas-Mirante Group, yielded younger radiometric ages, and their Nd isotopes indicate reworking from older material.

Many granitoid rocks of the São Francisco craton belong to large granite-greenstone or granitic-gneissic-migmatitic terrains, either in Bahia or Minas Gerais, formed in the Late Archean, close to 2.8-3.2 Ga. In Bahia, within the Gavião block and vicinities, many granitoid rocks (BA) exhibit negative initial $\varepsilon_{\mathrm{Nd}}$ values, indicating some crustal reworking from older crustal material.

However, in Minas Gerais, granitoid rocks of the Bonfim, Belo Horizonte, Campo Belo and similar old complexes (MG) are plotted close to the mantle evolution curves, indicating predominance of juvenile components in their protoliths. The late Archean high-grade rocks of the Jequié Complex $(\mathrm{J})$ in Bahia are also plotted near the mantle evolution curve, showing that very probably they are in a higher metamorphic grade, not equivalent to the nearby Gavião block granitoids.

Another important episode of mantle-crust differentiation occurred in the Early Proterozoic, in association with the so-called Transamazonian orogenic cycle, when the Mineiro belt formed in Minas Gerais and western Bahia (MI) and the Itabuna belt (IT) formed in eastern Bahia. Proximity to the mantle differentiation curves indicates that both of these geotectonic units probably formed from juvenile material. To this Early to Mid Proterozoic tectonomagmatic episode also correspond the intrusion of granitoid rocks $(\mathrm{Gr})$, formed by reworked crustal material, into the ContendasMirante belt. On the other hand, granitoids of Lagoa Real (LR) are anorogenic, and linked to the Mid-Proterozoic distensional events of the Espinhaço cycle. Their negative $\varepsilon_{\mathrm{Nd}}$ values suggest that such granitoids were derived at least partially from pre-existent crustal material.

\section{Borborema province}

The Borborema province is made up by a series of crustal fragments which took part in the Late Proterozoic process of agglutination of West Gondwana by the general collision of the large West African and Congo-São Francisco cratonic masses. A detailed account of its evolution can be found in Van Schmus et al. (1995).

A large number of $\mathrm{Nd}$ isotopic determinations are available for this region, and only those which seem to be the most appropriate to demonstrate its geochemical evolution were included in Figure 4. From the basement exposures within the province, the largest group-

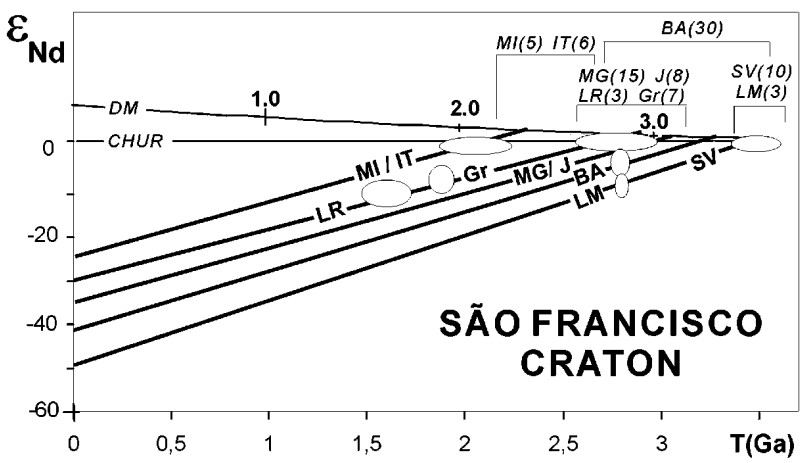

Figure 3 Diagram of Nd isotopic evolution for the São Francisco craton. $S V=$ Sete Voltas and Boa Vista gneissic domes; $L M=$ Lagoa do Morro basement gneisses; $B A=$ Gavião block and related terrains in Bahia; $M G=$ Bonfim, Belo Horizonte, and Campo Belo complexes in Minas Gerais; J = Jequié Complex; MI = Mineiro belt $;$ IT = Itabuna belt; $\mathbf{G r}=$ Intrusive granitoids into Contendas-Mirante belt; LR = Lagoa Real granitoids. 
ing of isotopic determinations belongs to the Rio Piranhas massif (P), where the early Proterozoic rocks yielded moderately negative initial $\varepsilon_{\mathrm{Nd}}$ values, indicative of at least partial reworking from crustal material of possible Archean age. Moreover, clear indications of the existence of Archean rocks were obtained in a few samples from the Caldas Brandão (CB) and Riacho do Pontal (Po) basement rocks, plotted near the CHUR mantle evolution line. A different type of basement is exposed in the Pajéu-Paraiba belt (PP), where granitoids yielded radiometric ages around $1.0 \mathrm{Ga}$. with moderately negative $\varepsilon_{\mathrm{Nd}}$ values, indicative of crustal protoliths of possible Proterozoic age.

Granitoid rocks are widespread throughout the Borborema province, intrusive either into its basement rocks or into the various volcanic-sedimentary supracrustal belts, and their radiometric ages are usually between 650-530 Ma. More than 50 samples of such granitoids were analysed and their $\mathrm{Nd}$ isotopic compositions fall in two ellipses ( $\mathrm{Gr} 1$ and $\mathrm{Gr} 2)$ in Figure 4. Their position in the Nd isotopic evolution diagram indicates that they cannot be directly derived by partial or total fusion of the Archean basement rocks already described. Some juvenile components differentiated from the mantle during Late Proterozoic times must be involved in their generation.

\section{Tocantins province}

The Tocantins tectonic province occupies a large portion of Central Brazil, and is made up of a series of cratonic fragments which took part in the collision between the large continental masses of the Amazonian and São Francisco cratons. This collisional process took place in the Late Proterozoic, when the entire province was affected by and partially reworked in the Brasiliano orogenic cycle. The main

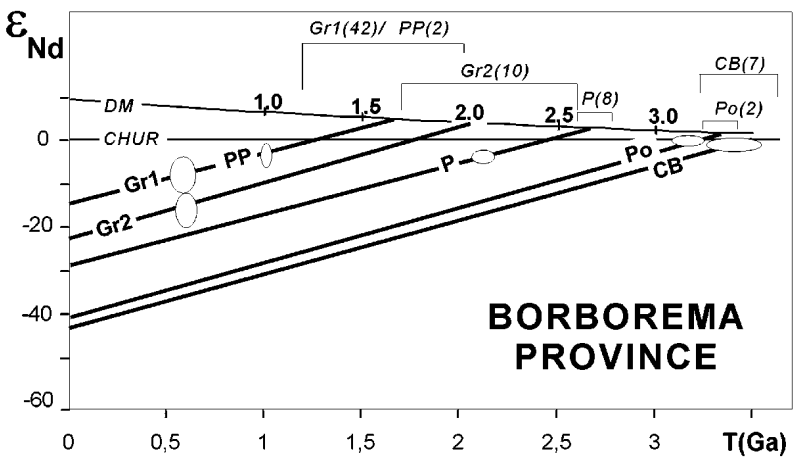

Figure 4 Diagram of $\mathrm{Nd}$ isotopic evolution for the Borborema province. $P=$ Rio Piranhas massif; $C B=$ Caldas Brandão basement gneisses; Po = Riacho do Pontal basement gneisses; $P P=$ Pajéu-Paraiba basement gneisses; Gr1 and Gr2 = Intrusive granitoids.

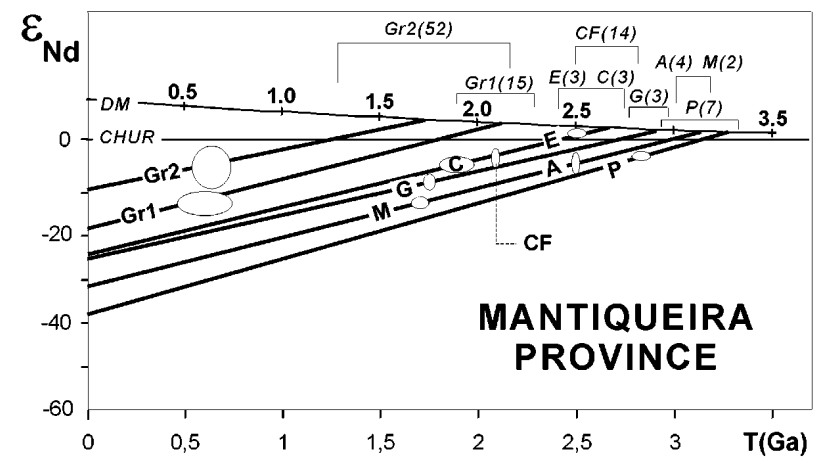

Figure 6 Diagram of Nd isotopic evolution for the Mantiqueira province. $P=$ Piripá terrain; $A=$ Amparo terrain; $E=E m b u$ terrain; $\boldsymbol{C F}=$ Cabo Frio crustal fragment; $\boldsymbol{C}=$ Curitiba massif; $G=$ Guanhães terrain; $M=$ Mantiqueira terrain; $G r 1$ and $G r 2=$ Intrusive granitoids. megasuture related to this event was identified as the Transbrasiliano lineament, which crosses the entire region from northeast to southwest.

The Sm-Nd systematics for the province are shown in Figure 5, which clearly demonstrates that many granitoids from this region (GO) are formed by juvenile material, differentiated from the mantle in Late Proterozoic times. They were produced in a series of magmatic arcs during important episodes of crustal accretion, and occupy a large area along and in the vicinity of the Transbrasiliano lineament (Pimentel and Fuck, 1992).

Within the Archean cratonic fragment of Crixás, a few gneissic rocks $(\mathrm{CX})$ yielded $\mathrm{Sm}-\mathrm{Nd} \mathrm{T}_{\mathrm{DM}}$ model ages roughly concordant with the available $\mathrm{Rb}-\mathrm{Sr}$ determinations, indicating a juvenile mantle source for their protoliths. However, in other cases, such as the Uvá (U1 and U2) as well as the Ribeirão (R) granitoid gneisses, reworking from previous crustal protoliths of Archean age is indicated. This pattern can be most probably applied to other crustal fragments of the tectonic province. For instance in its northeastern region, including the localities of Natividade and Cavalcante (NC in Figure 5), the available $\mathrm{Nd}$ isotopic determinations in rocks formed very probably in the Early Proterozoic, yielded moderately negative initial $\varepsilon_{\mathrm{Nd}}$ values, indicative of crustal reworking from Late Archean crustal protoliths.

\section{Mantiqueira province}

The Mantiqueira tectonic province includes a series of crustal fragments of different age and tectonic evolution, which took part in the agglutination of the Gondwana Supercontinent, in Late Proterozoic times, through the interaction of the continental masses of the São

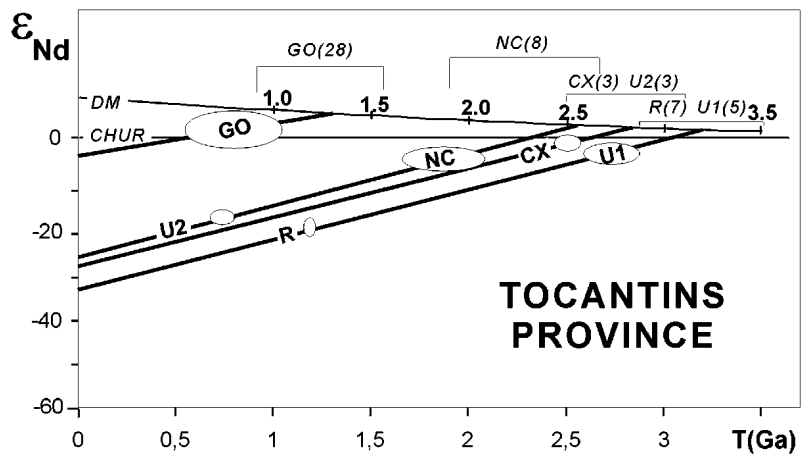

Figure 5 Diagram of $N d$ isotopic evolution for the Tocantins province. $G O=G r a n i t o i d s$ from Goiás magmatic arcs; $U 1$ and $U 2$ = Uvá basement gneisses; $C X=$ Crixás granitoid gneisses; $R=$ Ribeirão basement gneisses; $N C=$ Natividade and Cavalcante terrains.

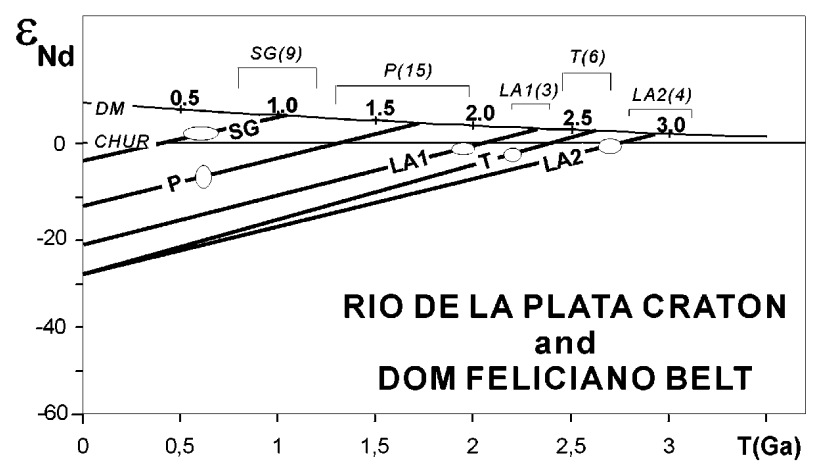

Figure 7 Diagram of Nd isotopic evolution for the Rio de La Plata craton and Don Feliciano belt. LA1 and LA2 = Luiz Alves cratonic fragment; $T=$ Basement gneisses within Tijucas belt; $P=$ Intrusive granitoids of Pelotas batholith $; \boldsymbol{S G}=$ Granitoids of São Gabriel block. 
Francisco-Congo and Kalahari cratons, as well as the Rio de La Plata and Luiz Alves cratonic fragments (Brito Neves and Cordani, 1991).

Figure 6 is the $\mathrm{Nd}$ isotopic evolution diagram for granitoid rocks from the so-called Araçuaí and Ribeira belts. The former is located within a large embayment of the São Francisco-Congo craton, and is considered as intracratonic and predominantly ensialic. The latter is made up of many allochtonous terrains of different origin and nature. Both units were affected by the tectonomagmatic episodes of the Brasiliano orogenic cycle.

With the exception of the Embu terrain (E) within the Ribeira belt, which yielded a juvenile Late Archean Nd isotopic signature, all the other "basement units" within both Araçuaí and Ribeira belts presented moderately to strongly negative initial $\varepsilon_{\mathrm{Nd}}$ values, indicating different types of reworking from Archean crustal protoliths. Such units are identified as Piripá (P), Amparo (A), Cabo Frio (CF), Curitiba (C), Guanhães (G) and Mantiqueira (M) in Figure 6. The oldest $\mathrm{Sm}-\mathrm{Nd} \mathrm{T}_{\mathrm{DM}}$ model age of about 3.2 Ga was obtained for the Late Archean Piripá basement terrain within the Araçuaí belt, a value which compares with those available for the adjacent Gavião block of the São Francisco craton. The other basement units are younger, most of them indicating an Early Proterozoic age and reworking of previous crustal material.

A large amount of granitoid rocks, belonging to many intrusive complexes, were formed in the Late Proterozoic during the tectonomagmatic episodes of the Brasiliano orogenic cycle. The Nd isotopic compositions of 67 granitoids fall into two groups with different initial $\varepsilon_{\mathrm{Nd}}$ values (Figure 6). Those with higher values (Gr1) correspond to magmatic intrusions into basement rocks of the Ribeira belt, probably formed by partial fusion from previous crustal material, in which an Early Proterozoic component seems to be predominant. The other group $(\mathrm{Gr} 2)$ includes intrusive granitoids in both the Araçuaí and Ribeira belts, and especially those considered by Campos Neto and Figueiredo (1995) as belonging to the Serra do Mar Microplate, the last allochtonous terrain which joined the previous collage in the process of agglutination of West Gondwana. These granitoid rocks exhibit a large spread in $\mathrm{Sm}-\mathrm{Nd} \mathrm{T}_{\mathrm{DM}}$ model ages, indicating that a probable Late Proterozoic juvenile component was present, mixed with different amounts of previous crustal material.

\section{Rio de La Plata and Luiz Alves cratonic fragments, and Dom Feliciano belt}

$\mathrm{Nd}$ isotopic determinations are not yet available for the main area of the Rio de La Plata craton. However, a few Sm-Nd T $\mathrm{DM}_{\mathrm{DM}}$ model ages were obtained from the area of the Luiz Alves cratonic fragment, and from rocks of the Dom Feliciano belt. They are reported in the $\mathrm{Nd}$ evolution diagram of Figure 7.

The high grade gneisses of the Luiz Alves cratonic fragment are plotted in two groups (LA1 and LA2), both in the vicinity of the CHUR mantle evolution line, and seem to correspond to two different episodes of mantle differentiation and continental crust formation, the older in the Late Archean, and the younger in the Early Proterozoic.

Within the Dom Feliciano belt, some basement gneisses (T) belonging to the Tijucas fold belt, with Early Proterozoic radiometric ages, yielded $\mathrm{Sm}-\mathrm{Nd} \mathrm{T}_{\mathrm{DM}}$ model ages at about $2.6 \mathrm{Ga}$., and slightly negative initial $\varepsilon_{\mathrm{Nd}}$ values, indicating some reworking from crustal materials.

In addition, a large number of intrusive granitoids belonging to the Pelotas batholith $(\mathrm{P})$ formed in Late Proterozoic times and yielded moderately negative initial $\varepsilon_{\mathrm{Nd}}$ values and Mid-Proterozoic $\mathrm{Sm}-\mathrm{Nd} \mathrm{T}_{\mathrm{DM}}$ model ages. They exhibit a large spread in the individual values, indicating very probably their formation within a root of a magmatic arc, where juvenile mantle-derived material was mixed with previously existent continental crustal material.

An interesting geotectonic feature of southern Brazil, whose geotectonic significance is not yet completely understood, is the so called São Gabriel block, where deformed granitoid gneisses (SG), affected by the Brasiliano orogeny, and yielding radiometric ages around $0.6 \mathrm{Ga}$, exhibited a juvenile, magmatic arc-type mantelic $\mathrm{Nd}$ isotopic signature, with slightly positive initial $\varepsilon_{\mathrm{Nd}}$ values.

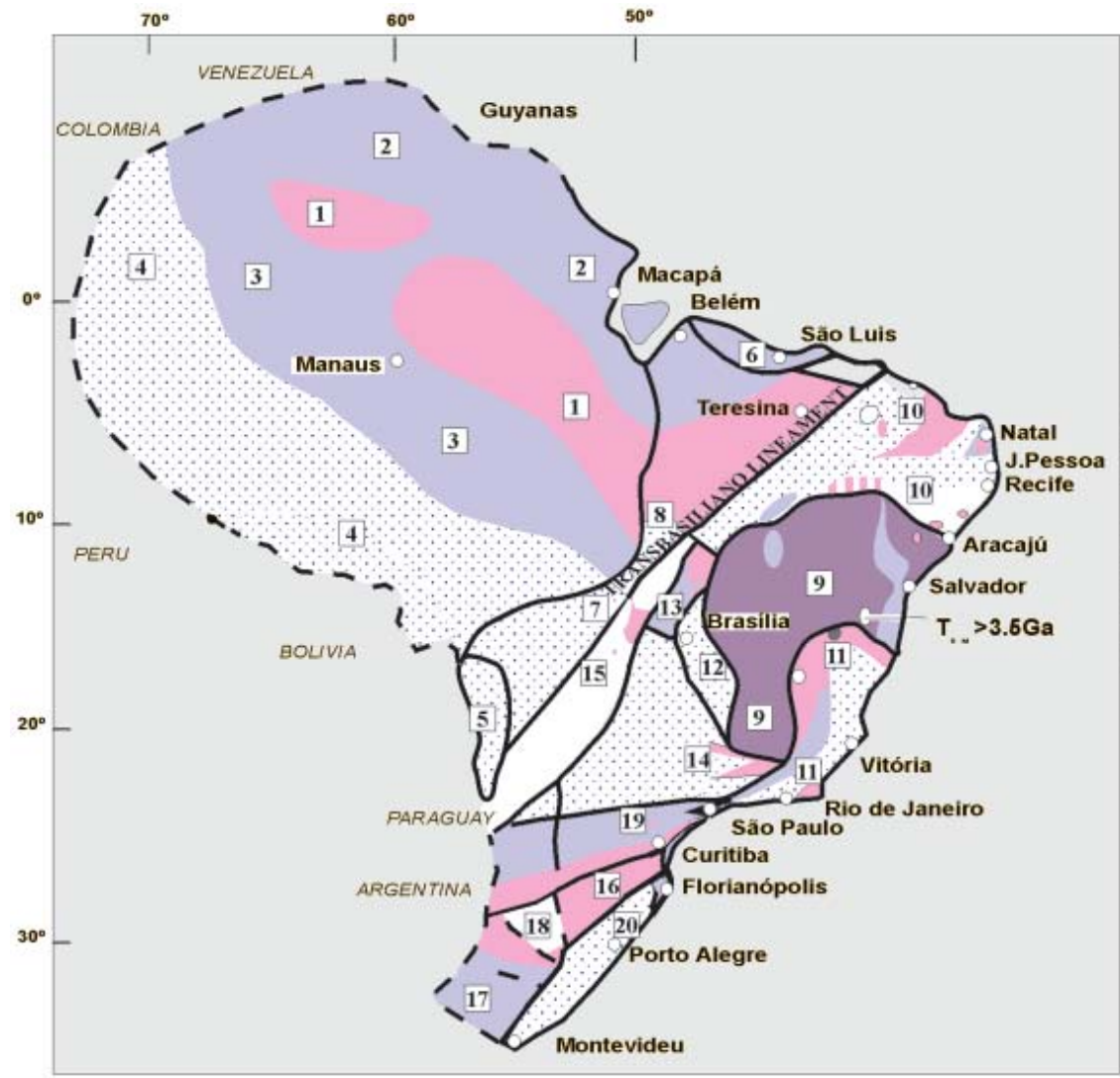

1. Central Amazonian Province

2. Maroni-Itacaiunas Province

3. Ventuari-Tapajós Province

4. Rio Negro-Juruena and

Rondonian Provinces

5. Rio Apa cratonic fragment

6. Săo Luis cratonic fragment

7. Tectonic domain of the Paraguay-Araguaia belt

8. Tectonic domain of the Tocantins belt

9. São Francisco craton

10. Tectonic domain of the Borborema Province

1. Tectonic domain of the Araçuai belt

12. Tectonic domain of the Brasilia belt

12. Tectonic domain of the Brasilia belt
13. Tectonic domain of the Uruaçu belt

14. Tectonic domain ot he Araxá and

Alto Rio Grande belts

15. Goiás magmatic arc

16. Luis Alves cratonic fragment

17. Rio de La Plata cratonic fragment

18. São Gabriel tectonic block

19. Ribeira belt

20. Dom Feliciano belt

Sm-Nd MODEL AGES

(T..)

3,5-3,0 Ga

3,0-2,5 Ga

2,5-2,0 Ga

2,0-1,5 Ga

$<1,5 \mathrm{Ga}$

Figure 8 Crustal domains of the South American Platform. 


\section{Concluding remarks}

For the Archean rocks of the South American Platform, the Sr and $\mathrm{Nd}$ isotopic systematics indicates essentially juvenile material, as in other parts of the world. The oldest rocks found so far in South America, the already mentioned Sete Voltas and Boa Vista granitoids from the Gavião block within the São Francisco craton, yielded $\mathrm{Sm}-\mathrm{Nd} \mathrm{T}_{\mathrm{DM}}$ model ages up to $3.7 \mathrm{Ga}$.

For Early to Mid Proterozoic rocks, both juvenile and reworked granitoids are found. In the eastern part of the platform, corresponding to the São Francisco craton and to the basement of the younger mobile belts which surround it, reworked material predominates. However, for the western part, and especially within the very large region of the Ventuari-Tapajós and the Rio Negro-Juruena tectonic provinces of the Amazonian craton, juvenile material is widespread. The geotectonic model for this region envisages continuing subduction of an oceanic lithospheric plate, with the formation of successive magmatic arcs, which accreted later onto the adjacent continental masses.

In Mid to Late Proterozoic times, granitoid rocks were either formed within the mobile belts of this age, or intruded the cratonic areas in the context of intraplate processes. In both cases, they seem to have originated by reworking of previous crustal material. Exceptions are the important Late Proterozoic magmatic arcs near the Transbrasiliano lineament in Central Brazil, and within the São Gabriel tectonic block in southern Brazil.

The South American Platform was subsequently divided into crustal domains with internally coherent structural evolution and geochronological pattern. Figure 8, showing these domains, retains the main boundaries of Figure 1, but the Amazonian craton was further subdivided according to its internal tectonic provinces, and the Late Proterozoic provinces affected by the Brasiliano orogeny were subdivided into smaller domains. Where the Precambrian basement is concealed beneath the sedimentary rocks of the Amazonian, Parnaiba and Paraná basins, the crustal domains were extrapolated with the help of some drill core informations. The extension of the South American Platform beneath the Andean foredeep basins (Llanos, Beni, Chaco, Pampas) was not considered, because of complete lack of information. The area included in Figure 8 includes Brazil, French Guiana, Guyana, Surinam, Uruguay, and parts of Bolivia, Venezuela, Paraguay and Argentina, comprising $9.3 \times 10^{6} \mathrm{~km}^{2}$.

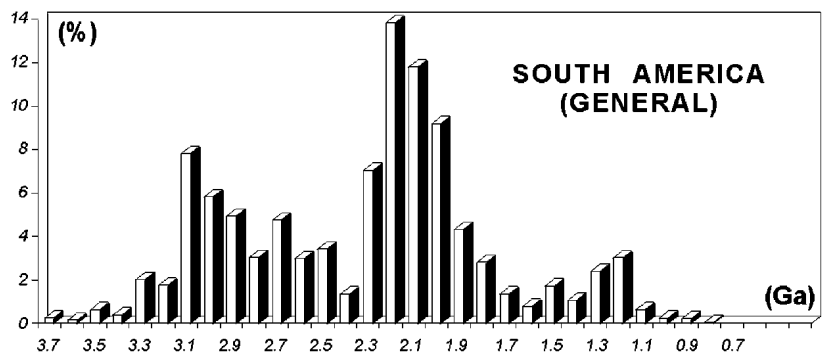

Figure 9 Histogram of continental growth (or survival) for the South American Platform.

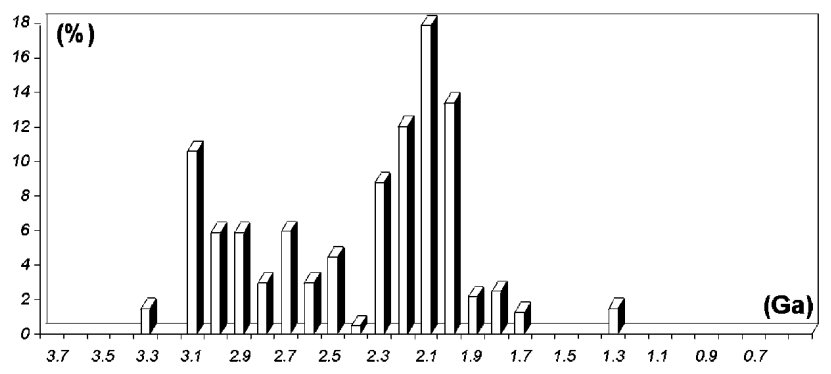

Figure 11 Histogram of continental growth (or survival) for the northwestern part of the South American Platform.
All available Sm-Nd T $\mathrm{T}_{\mathrm{DM}}$ values were employed for the construction of the histogram of Figure 9, where the areas of each of the crustal domains indicated in Figure 8 were taken into account. It is apparent that small amounts of continental crust older than $3.3 \mathrm{Ga}$ survived within Archean fragments formed between 3.1 and $2.6 \mathrm{Ga}$. However, the main period of continental crust formation was between 2.2 and $2.0 \mathrm{Ga}$, in Early Proterozoic times, corresponding to the Transamazonian orogenic cycle. The predominance of Early Proterozoic juvenile meterial in the histogram is due to the very large area within the Amazonian craton consisting of juvenile magmatic arcs. Accretion of juvenile material continued into the Late Proterozoic, but at much slower rates. A small peak on the histogram corresponds to the Espinhaço/Rondonian cycle (1.2-1.3 Ga) but contribution of the Brasiliano orogenic cycle is barely visible in the figure. The continental growth (or survival) curve derived from the $\mathrm{Sm}-\mathrm{Nd}$ measurements (curve 2 in Figure 10) is not very much different from the one based in the $\mathrm{Rb}-\mathrm{Sr}$ results. It indicates that about $34 \%$ of the present crust was formed in the Archean, $80 \%$ by the end of the Transamazonian cycle, and about $98 \%$ at the onset of the Brasiliano cycle, in Late Proterozoic times.

The Transbrasiliano lineament is a megasuture which separates a large northwestern continental mass, including the Amazonian craton, from a southeastern continental mass, formed by a collage of cratonic fragments of different sizes, of which the São Francisco craton is the largest. When the crustal evolution of these two large continental masses is considered individually ( see Figures 11 and 12), a few conclusions can be made:

1 - Old Archean rocks (older than $3.3 \mathrm{Ga}$.) can be found at present only within the southeastern part of the South American Platform.

2 - On both continental masses, crustal evolution between 3.0 and $1.7 \mathrm{Ga}$ is roughly similar, suggesting that they were possibly contiguous within an Early Proterozoic supercontinent.

3 - During Mid and Late Proterozoic times, the northwestern continental mass remained virtually unaffected by tecto-orogenic events, while the southeastern mass underwent disruption into smaller cratonic fragments, with the concomitant formation of regions of oceanic floor. Later, these small plates, microcontinents and pieces of continental and oceanic lithosphere, took part in the

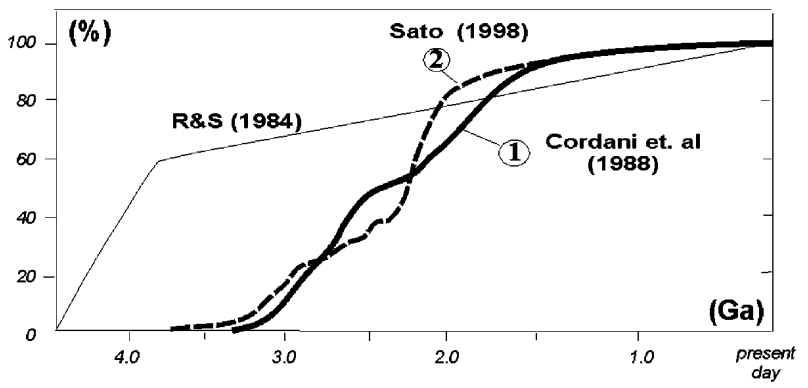

Figure 10 Cumulative curves for continental growth (or survival) for the South American platform. (1) - From Cordani et al. (1988), based on Sr isotopes, and (2) - This work, based on Nd isotopes.

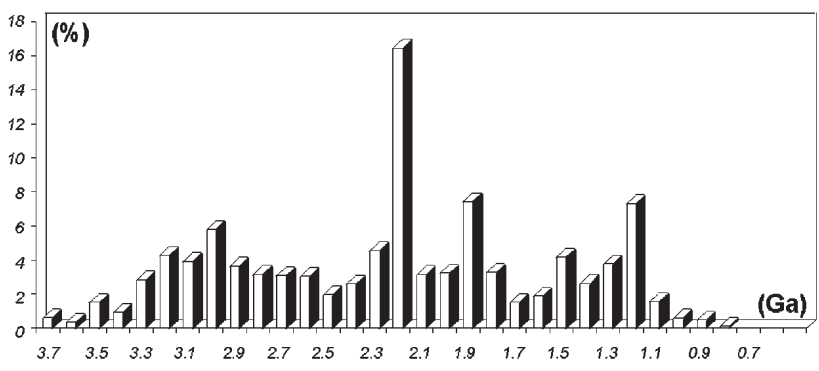

Figure 12 Histogram of continental growth (or survival) for the southeastern part of the South American Platform. 
agglutination and later fragmentation of at least two large supercontinents, Rodinia and Gondwana.

\section{Acknowledgements}

The authors are grateful to many colleagues of the Geochronology Research Center - USP for their help in the analytical work and fruitful discussions. This work was supported by grants from the Brazilian Ministry of Science and Technology (PRONEX 41.96.0899.00) and the São Paulo State Foundation of Research Support (FAPESP 95/4652-2).

\section{References}

Arndt, N. T. and Goldstein, S. L., 1987, Use and abuse of crust-formation ages: Geology, 15: 893-895.

Brito Neves, B. B. and Cordani U. G., 1991, Tectonic evolution of South America during the Late Proterozoic: Prec. Research, 53: 23-40.

Campos Neto, M. C. and Figueiredo, M. C. H., 1995, The Rio Doce Orogeny, Southeastern Brazil: Jour. South. Amer. Earth Sci., 8: 143-162.

Cordani, U. G. and Brito Neves, B. B., 1982, The geologic evolution of South America during the Archaean and Early Proterozoic: Rev. Bras. de Geociências, S. Paulo, 12 (1-3): 78-88.

Cordani, U. G.; Teixeira, W., Tassinari, C. C. G., Kawashita. K. and Sato, K., 1988, The growth of the Brazilian Shield: Episodes, vol 11 (3): 163-167.

De Paolo, D. J., 1980, Crustal growth and mantle evolution: Inferences from models of element transport and $\mathrm{Nd}$ and $\mathrm{Sr}$ isotopes: Geochem. Cosmochim. Acta, 44: 1185-1196.

De Paolo, D. J., 1988., Age dependence of the composition of continental crust : evidence from $\mathrm{Nd}$ isotopic composition in granitic rocks: Earth Plan. Sci. Letters, $90: 263-271$.

Nutman, A. and Cordani, U. G., 1993, SHRIMP U-Pb zircon geochronology of Archean granitoids from the Contendas-Mirante area of the São Francisco Craton, Bahia, Brazil: Prec. Research, 63: 179-188.

Pimentel, M. M. and Fuck, R., 1992, Neoproterozoic crustal accretion in central Brazil: Geology, 20: 375-379.

Sato, K., 1998, Evolução crustal da Plataforma Sul Americana, com base na geoquímica isotópica Sm-Nd - Doctoral Thesis, Institute of Geosciences, University of São Paulo.

Schobbenhaus, C., Campos, D. de A., Derze, G. R., and Asmus, H. E., 1984, Geologia do Brasil: Texto Explicativo do Mapa Geológico do Brasil e Àrea Oceânica Adjacente - D.N.P.M. - Brasilia.

Teixeira, W., Tassinari, C. C. G., Cordani, U. G., and Kawashita, K., 1989, A review of the geochronology of the Amazonian Craton: Tectonic implications. Prec. Research, 42: 213-227.

Van Schmus, W. R., Brito Neves, B. B., Hackspacher, P. C.and Babinski, M., $1995, \mathrm{U} / \mathrm{Pb}$ and $\mathrm{Sm} / \mathrm{Nd}$ geochronologic studies of the eastern Borborema Province, Northeastern Brazil: Initial conclusions: Jour. South Amer. Earth Sci., 8: 267-288.
Umberto G. Cordani, former President of IUGS (1988-1992), graduated in Geology at the University of São Paulo (USP), Brazil, where he made a complete academic career up to the position of Full Professor in 1980. He was Director of the Institute of Geosciences and of the Institute of Advanced Studies in the same University, where he presently occupies the position of Chairman of the International Cooperation Commission.

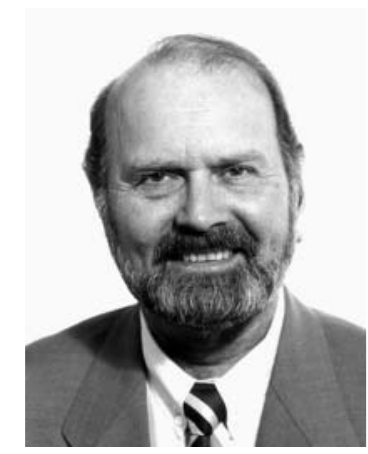

Kei Sato physicist, researcher at the Geochronology Research Center of the University of São Paulo. He obtained his Dr. Sc. in Geochemistry and Geotectonics at the USP, and his main research interests are in Geochronology, especially related to the Sm-Nd method. Presently he is coordinator of the mass spectrometric laboratory of the CPGeo-USP.

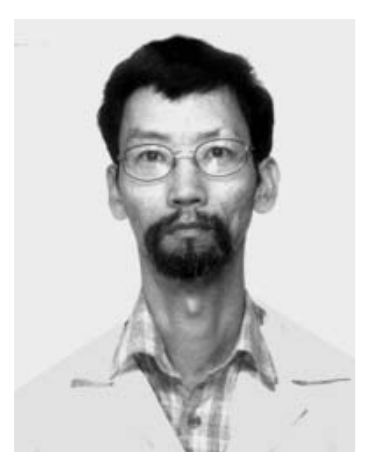

